\title{
Integrating agronomic factors into energy efficiency assessment of agro-bioenergy production - A case study of ethanol and biogas production from maize feedstock
}

\author{
Oludunsin Tunrayo Arodudu ${ }^{\mathrm{a}, \mathrm{b}, *}$, Katharina Helming ${ }^{\mathrm{a}, \mathrm{d}}$, Alexey Voinov ${ }^{\mathrm{c}}$, Hubert Wiggering ${ }^{\mathrm{b}}$ \\ ${ }^{a}$ Leibniz Centre for Agricultural Landscape Research (ZALF), Eberswalder Straße 84, 15374 Müncheberg, Germany \\ ${ }^{\mathrm{b}}$ Potsdam University, Institute of Earth and Environmental Sciences, Karl-Liebknecht-Straße 24-25, 14476 Potsdam-Golm, Germany \\ ${ }^{\mathrm{c}}$ ITC, Faculty of Geoinformation and Earth Observation, University of Twente, Hengelosestraat 99, Enschede, Netherlands \\ ${ }^{\mathrm{d}}$ Faculty of Landscape Management and Nature Conservation, University for Sustainable Development (HNEE), Schickler Strasse 5, 16225 Eberswalde, Germany
}

\section{H I G H L I G H T S}

- Effect of agronomic factors on agrobioenergy LCA were considered.

- Effect of farm power, irrigation, fertilizer, tillage and seed options were assessed.

- EROEI of ethanol and biogas from maize increased to 2.1-3 and 15-33.9 respectively.

- Hybrid and GMO seeds have neutral to negative impacts on biofuel's energy efficiency.

- Fertilizer has the highest overall impact on the energy efficiency of biofuels.

\section{A R T I C L E I N F O}

\section{Article history:}

Received 1 November 2016

Received in revised form 4 February 2017

Accepted 7 February 2017

Available online 20 February 2017

\section{Keywords:}

LCA

NEG

EROEI

Agro-climatic zones

Maize ethanol and biogas production systems

Agronomic factors

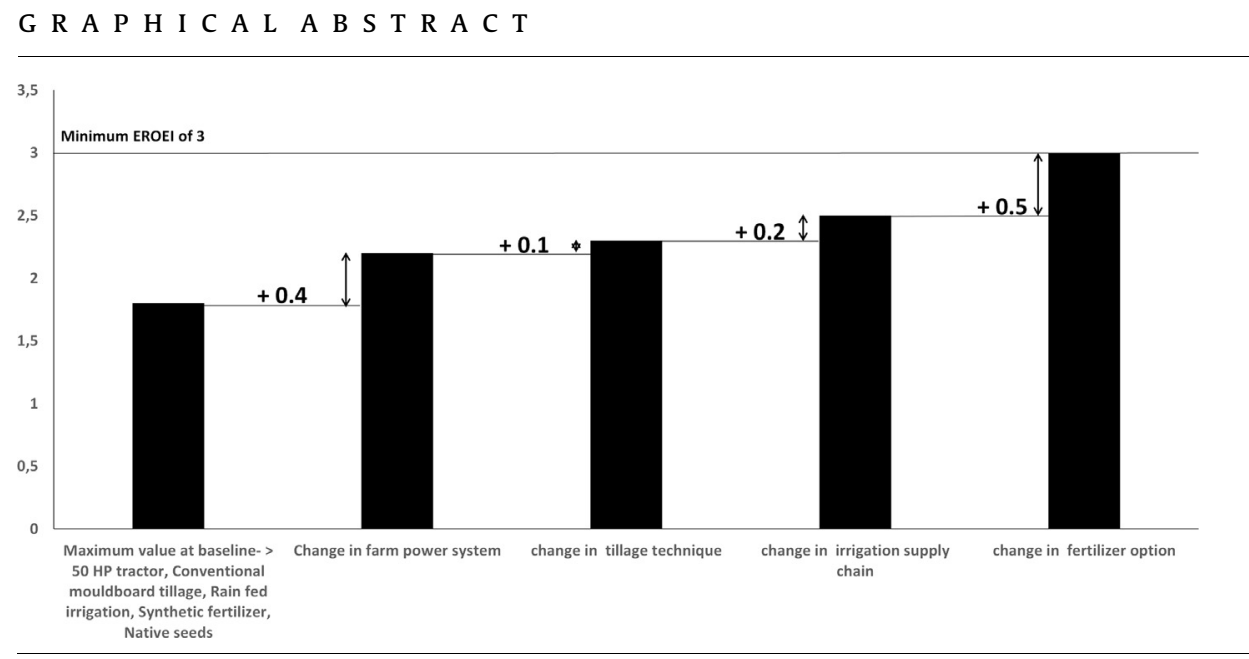

\begin{abstract}
A B S T R A C T
Previous life cycle assessments for agro-bioenergy production rarely considered some agronomic factors with local and regional impacts. While many studies have found the environmental and socio-economic impacts of producing bioenergy on arable land not good enough to be considered sustainable, others consider it still as one of the most effective direct emission reduction and fossil fuel replacement measures. This study improved LCA methods in order to examine the individual and combined effects of often overlooked agronomic factors (e.g. alternative farm power, seed sowing, fertilizer, tillage and irrigation options) on life-cycle energy indicators (net energy gain-NEG, energy return on energy investedEROEI), across the three major agro-climatic zones namely tropic, sub-tropic and the temperate landscapes. From this study, we found that individual as well as combined effects of agronomic factors may improve the energy productivity of arable bioenergy sources considerably in terms of the NEG (from between 6.8 and $32.9 \mathrm{GJ} /$ ha to between 99.5 and $246.7 \mathrm{GJ} /$ ha for maize ethanol; from between 39.0 and $118.4 \mathrm{GJ} /$ ha to between 127.9 and $257.9 \mathrm{GJ} /$ ha for maize biogas) and EROEI (from between 1.2 and 1.8 to between 2.1 and 3.0 for maize ethanol, from between 4.3 and 12.1 to between 15.0 and 33.9 for maize biogas). The agronomic factors considered by this study accounted for an extra 7.5-14.6 times more of NEG from maize ethanol, an extra 2.2-3.3 times more of NEG from maize biogas, an extra 1.7 to 1.8 times
\end{abstract}


more of EROEI from maize ethanol, and an extra 2.8-3.5 times more of EROEI from maize biogas respectively. This therefore underscores the need to factor in local and regional agronomic factors into energy efficiency and sustainability assessments, as well as decision making processes regarding the application of energy from products of agro-bioenergy production.

(C) 2017 Elsevier Ltd. All rights reserved.

\section{Introduction}

The global agricultural-bioenergy value chain is very diverse [1-3], broad scientific generalizations on the sustainability of bioenergy produced on arable lands without adequate consideration of the effects of certain local and regional (farming system level) agronomic factor options (e.g. alternative farm power, irrigation, tillage, fertilizer and seed sowing options etc.) can lead to inaccurate conclusions regarding their local and regional applications for socio-economic functions (e.g. fossil fuel replacements, vehicle fuel etc.) [4-6]. In response to this, this study modified the boundaries of previous life cycle assessment (LCA) frameworks, in order to estimate the effects that these agronomic factor options have on the sustainability and applicability of agro-bioenergy production systems.

Previous LCA for sustainability assessment often consider conventional tillage as the norm for biomass produced from arable land; however in practice many farmers adopt conservation tillage (e.g. no till, stubble mulch, chisel, disk, ridge-plant, strip-till etc.) in order to minimize the effects on soil degradation processes $[7,8]$. This is a local factor that is often overlooked in most LCA studies for agro-bioenergy production $[9,10]$. Sustainability assessments of agro-bioenergy systems should not only feature conventional tillage but also conservation tillage systems (i.e. reduced and notill systems), whenever adopted [11-13].

The effects of the use of alternative farm inputs e.g. animal manure or biogas digestate as opposed to synthetic fertilizers, hybrid or GMO (genetically modified organisms) seeds against the use of native seeds etc. are also rarely considered in estimating the NEG and EROEI across bioenergy production chains from arable land $[2,14]$. While previous LCAs for biomass production on arable land assume the use of only high horse-power (HP) tractors (e.g. four wheel drive $50 \mathrm{HP}$ and above) [7,10], small-scale farmers (especially in developing countries) can only afford lower HP tractors (e.g. single-axle tractors) and in some cases only animal and/or human labour $[8,12]$. Even though production by small scale farmers is limited by scale and therefore may not be suitable for large scale (commercial) bioenergy production, in the event of severe energy demand (occasioned by climate change mitigation restrictions and global fossil fuel depletion/scarcity), small scale farmers (especially in rural areas) will need energy to drive their agrarian based local economy, and may therefore be forced to form networks (i.e. partnerships or cooperatives) aimed at harnessing their bioenergy potential (using energy crops, agricultural wastes etc.), as well as other renewable energy sources $[15,16]$. Also, due to the difference in agro-ecological and climatic conditions, the effects of using different irrigation options as opposed to production under rain-fed conditions is rarely discussed within the framework of LCA studies for agro-bioenergy systems [8,17].

Previously, the sustainability of bioenergy production has often been assessed in terms of LCA based energy efficiency indicators such as the net energy gain (NEG) and energy return on energy invested (EROEI) $[18,19]$. This is because the net energy gain (NEG) indicator measures the effectiveness of bioenergy production activities in contributing to set renewable energy targets $[18,20]$ on the one hand; while the energy return on energy invested (EROEI) is a fair indicator of the capacity of a bioenergy production activity to support continuous socio-economic functions, regardless of the effects of externalities such as soil degradation, water pollution, biodiversity impacts, price fluctuations etc. $[17,19]$. In this study, we assessed the sensitivity of these energy efficiency indicators (NEG and EROEI) to the above listed agronomic factors using maize feedstock cultivation for ethanol and biogas production at generic agro-climatic zone levels (i.e. tropics-Latitude $0-23.5^{\circ} \mathrm{N}$ and $\mathrm{S}$, sub-tropics- Latitude $23.6-40^{\circ} \mathrm{N}$ and $\mathrm{S}$ and temperate-Latitude $40.1-60^{\circ} \mathrm{N}$ and $\mathrm{S}$ ) as case studies. A wide range of data across the different agro-climatic zones was examined, in order to capture the extent of the sensitivity of the two energy efficiency indicators to the listed agronomic factors globally. This study explicitly assessed the individual and cumulative effects of the listed agronomic factors on NEG and EROEI, especially with respect to the feasibility of application and usage for different energy related socio-economic functions (e.g. fossil fuel replacements, vehicle fuel etc.). The information on the effects of agronomic factor options will offer improved understanding relevant for future energy efficiency improvements to decision makers (from an LCA perspective).

Maize was chosen as a case study because it is the agricultural biomass feedstock with the highest contribution (at least 35\%) to global biofuel production $[21,22]$. Maize is widely cultivatable globally across several agro-ecological and climatic conditions because it exhibits high photosynthetic and water-use efficiency properties, even under conditions of drought, high temperatures, and nitrogen or $\mathrm{CO}_{2}$ limitations [7,23]. Maize has relatively high carbon fixation and assimilation capacity $[24,25]$. It is also capable of high yield and high energy output-input ratio (in terms of energy use efficiency or fossil energy intensity) when compared to other major crops (maize-4.0-7.7, soybeans-3.2-4.6. rice-2.2, winter wheat-2.1, potato-1.3, sugar cane-1.2.2.1 etc.) $[10,24,26-$ 28]. Since analysis within this study focus more on the effects of field-based agronomic factor options (and not production steps that vary in energy consumption from one energy conversion technology to the other), the methodology adopted, as well as the findings and inferences from this study can be further applied and extrapolated for other crops grown for energy production purposes, as well as other biomass production activities on arable land. Ethanol and biogas production technologies were chosen because they are both widely used globally. Ethanol and biogas are particularly important because they are in high demand for meeting future global sustainability targets such as global greenhouse gas emission reduction, fossil fuel replacement and renewable energy targets $[29,30]$. Ethanol production has contributed immensely to the meeting of different biofuel mandates (e.g. E10, E15, E25 and E85 gasoline mix, as well as E100) aimed at reducing fossil fuel consumption and associated greenhouse gas emissions $[2,12]$. Biogas production on the other hand has been widely promoted for its capacity to utilize wide range and different mixes of biomass flows (waste biomass inclusive); and its ease of implementation in smaller units [20,31].

\section{Methodology}

The methodology involved a life cycle assessment (LCA) approach, which substitutes individual energy and material flows 
(inputs and outputs) within the boundaries of previous agrobioenergy LCA studies, in order to further account for the effects of agronomic factors such as alternative farm power, irrigation, tillage, fertilizer and seed-sowing options.

In considering the effects of each agronomic factor sub-option on the energy efficiency of biofuel production systems, a baseline option was chosen for the different agronomic factor categories (i.e. farm power, irrigation, tillage, fertilizer and seed-sowing options). The effects of other options within the same agronomic factor categories were assessed by substituting the energies inputs associated with adopting them with those of the baseline options. This is further illustrated in Fig. 1.

As seen in Fig. 1, the baseline option selected for the farm power agronomic factor category was four wheel drive $>50 \mathrm{HP}$ tractors. The baseline option selected for irrigation, tillage, fertilizer and seed-sowing agronomic factor categories were rain-fed irrigation, conventional mouldboard tillage with pesticide application, synthetic fertilizer and native seeds respectively.
Also from Fig. 1, other farm power options considered included various tractor implementations (two wheel drive 21-49 HP tractors, single axle riding type 10-20 HP tractors and ordinary single axle $<9$ HP tractors), several animal labour options (ox, buffalo, horse, donkey, mule, camel) as well as human labour. Other fertilizer options whose effects were assessed included animal manure and biogas digestate. Other seed-sowing options examined included hybrid and GMO seeds. Other tillage options evaluated included conventional tillage options such as mouldboard tillage without pesticide application; reduced tillage options such as ridge plant, disk, chisel, and stubble and mulch tillage; and no tillage options such as no-till and strip-till options. Other irrigation options also looked at included artificial irrigation options such as surface, sprinkler and drip irrigation systems.

Noteworthy however is the fact that the baselines selected for agronomic factor categories within the context of this study were not selected because they are most representative of realities across the three agro-climatic zones, they were chosen only to

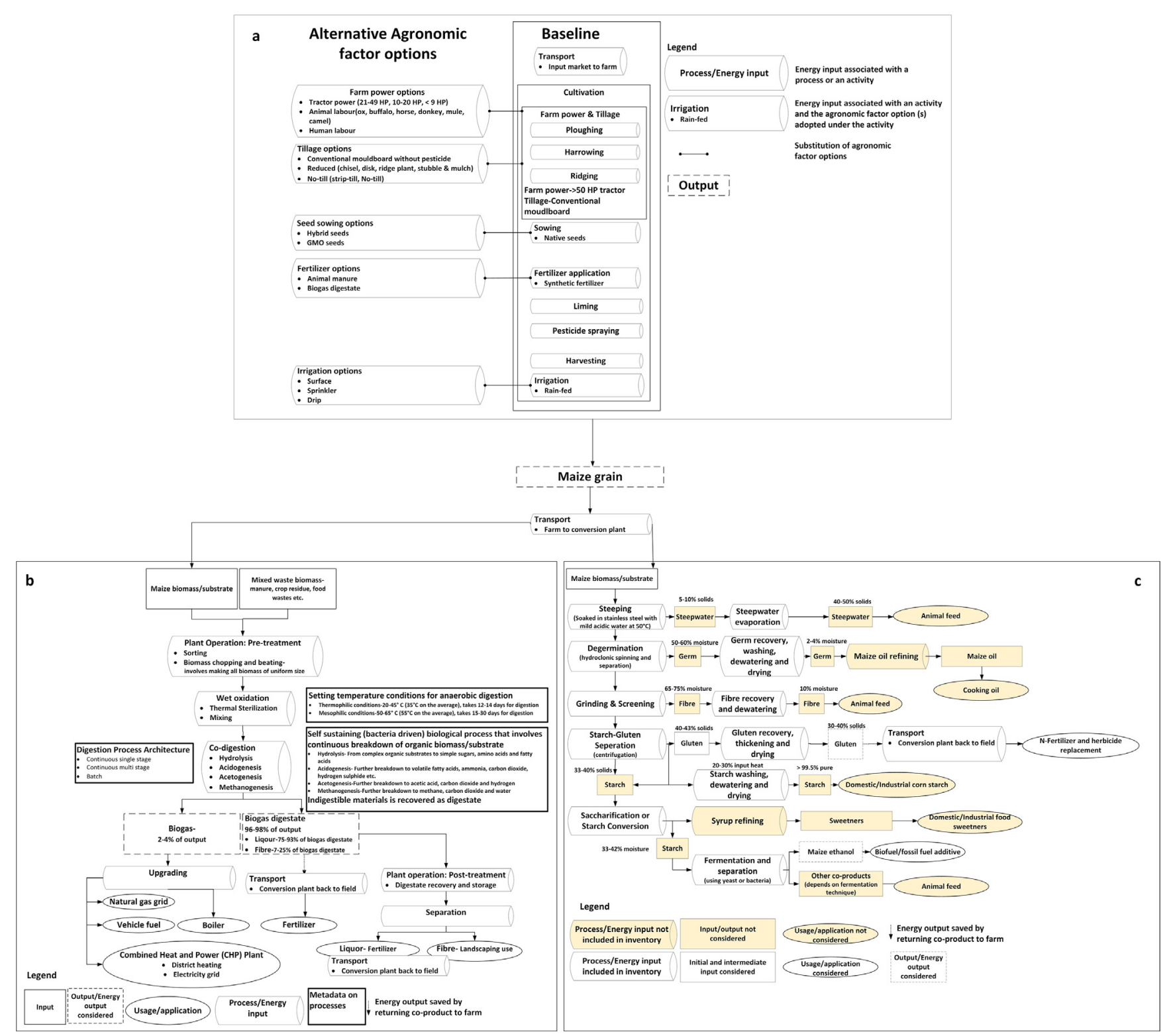

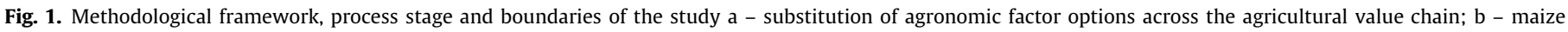
biogas bio-refinery value chain; c-maize ethanol bio-refinery value chain. 
enable the assessment of the effects of individual agronomic factor options on the energy efficiency of agricultural based bioenergy production systems (on an LCA basis). Section 2.1 elaborates more on how the two energy efficiency indicators (NEG and EROEI) are estimated; Section 2.2 explains the scope of the study, as well as its boundaries and assumptions made in the course of the study; while Section 2.3 describes how results obtained from the substitution of one agronomic factor with another (i.e. individual agronomic factor effects) are added up to assess the overall significance of often overlooked agronomic factors on the energy efficiency of agro-bioenergy production systems.

\subsection{Life cycle inventory ( $L C I)$}

A life cycle inventory ( $\mathrm{LCI}$ ) (which is the inventory phase of an LCA) was done in order to calculate the net energy and the energy efficiencies of the agro-bioenergy production system. This involves accounting for the direct energy inputs into cultivation (e.g. energy for ploughing, harrowing, ridging, seed sowing, fertilizer application, pesticide application, liming, irrigation, harvesting etc.), transportation (e.g. from farm to input market, input market to farm, farm to bio-refinery, bio-refinery to farm etc.) and conversion of biomass to energy on the one hand (i.e. energy for plant operations), and indirect energies for production of used chemicals (fuels, fertilizers, herbicides, lime etc.) on the other hand [19,32]. Energy output obtainable from biofuels (maize ethanol and maize biogas) and substitution effects of co-products were also accounted for $[14,17]$. Maize biogas digestate obtained from wet co-digestion process (i.e. co-digestion of maize with manure) of the maize biogas production system was accounted for as fertilizer (N, P and $\mathrm{K}$ ) and lime replacements. Maize gluten meal obtained from wet milling process of maize ethanol production system was accounted for as N-fertilizer and herbicide replacements [33,34]. This is further illustrated in Fig. 1.

The total energy inputs and outputs obtained are used for calculating the following energy indicators:

Net energy gain $(\mathrm{NEG})=$ Energy Output - Energy input

NEG may be quantified in Joules (J) or Joules/hectare cultivated $(\mathrm{J} / \mathrm{ha})$ or Joules/tonnes of biomass used $(\mathrm{J} / \mathrm{t})$, depending on the reference system chosen by each study $[18,35]$;

Energy return on energy invested (EROEI)

$$
=\text { Energy output/Energy input }
$$

EROEI has no units. It is essentially the fraction of energy obtained after energy investment in an energy production activity. It is sometimes referred to as the energy efficiency of the energy system being assessed [2,19].

\subsection{Scope, boundaries and assumptions}

These assumptions marking the LCI boundaries of this study can be classified into two types. Those pertaining to LCI boundaries at baseline, and those made as a result of the substitution of agronomic factor options across the different agronomic factor categories.

\subsubsection{Assumptions with regards to LCI boundaries at baseline include}

\section{Maximum transport or travel distance}

- Maximum transport or travel distance was assumed to be between 10 and $20 \mathrm{~km}$. In other words, the maximum travel distance between farm and input market or input market and farm, farm and conversion plant or conversion plant to farm, for the purpose of cultivating maize and converting it to biofuels for use within local and/or regional agricultural sector does not exceed $10-20 \mathrm{~km}$. Conversion plants were assumed to be farm-based, small scale, and located optimally close to the farm and input markets.

\section{Reference unit system}

- The reference unit system examined was Joules (J) of energy produced from maize ethanol and maize biogas production system. The assumed farmland size cultivated and corresponding crop yields, as well as the seed, fertilizer, lime and pesticide application rates were however all on a per hectare per year basis.

\section{Potential maize yield}

- In order to estimate potential maize yields across the agro-climatic zones considered, data of best fertilizer management practices and average maize yields in different countries and regions across the agro-climatic zones were used to derive regression equations. Best fertilizer management practices and average maize yields data from Indonesia, Thailand, Brazil, Cambodia and Malawi were assumed to represent the tropics. Best fertilizer management practices and average maize yields from SE United States and South Africa were assumed to represent the sub-tropics. Best fertilizer management practices and average maize yields from NE United States and France were assumed to represent the temperate zone). The regression equations were used to estimate the potential maize yields across the different agro-climatic zones, assuming $\mathrm{N}$-fertilization rates are $30 \mathrm{~kg} / \mathrm{ha}, 60 \mathrm{~kg} / \mathrm{ha}, 90 \mathrm{~kg} / \mathrm{ha}, 120 \mathrm{~kg} / \mathrm{ha}, 150 \mathrm{~kg} / \mathrm{ha}, 180 \mathrm{~kg} /$ ha and $210 \mathrm{~kg} /$ ha respectively. The source data for best fertilizer management practices and average country maize yields, as well as the values of N-Fertilizer application assumed and the corresponding estimates of potential maize yields are documented in Tables S1-S3, as well as Figs. S1 and S2 [36-41].

\section{Transportation of inputs, outputs and co-product}

- Due to lack of precise data on the energy for transport of inputs, outputs and co-products, they were assumed to be between those of sugar beet and grasses 0.0048$0.0058 \mathrm{MJ} / \mathrm{kg} / \mathrm{km}$ [42]. This is because they have different densities within which the density of inputs, outputs and co-products are likely to fall (either as light as grass at the lower limit or as heavy as sugar beet at the upper limit). However, the energy for transport of manure and biogas digestate was assumed to be essentially the same (as heavy as cow or pig manure), considerably heavier and different from those of fertilizers, pesticides, lime etc. $(0.014 \mathrm{MJ} / \mathrm{kg} /$ $\mathrm{km}$ ) [42]. While these conversion factors are not exact they are conservative and therefore acceptable.

\section{Energy for machineries}

- Embodied energy for manufacturing, start-up and maintenance of machineries (e.g. tractors, irrigation systems, biorefineries etc.) was avoided by this study because it may confer significant advantage on the energy input side and skew the LCA; and also because it is mostly within the domain of life cycle costing for potential investors and entrepreneurs.

The conversion factors for all energy inputs and energy outputs considered at baselines can be found in Tables 1 and 2 respectively. 
Table 1

Conversion factors for estimating energy inputs of the baseline options.

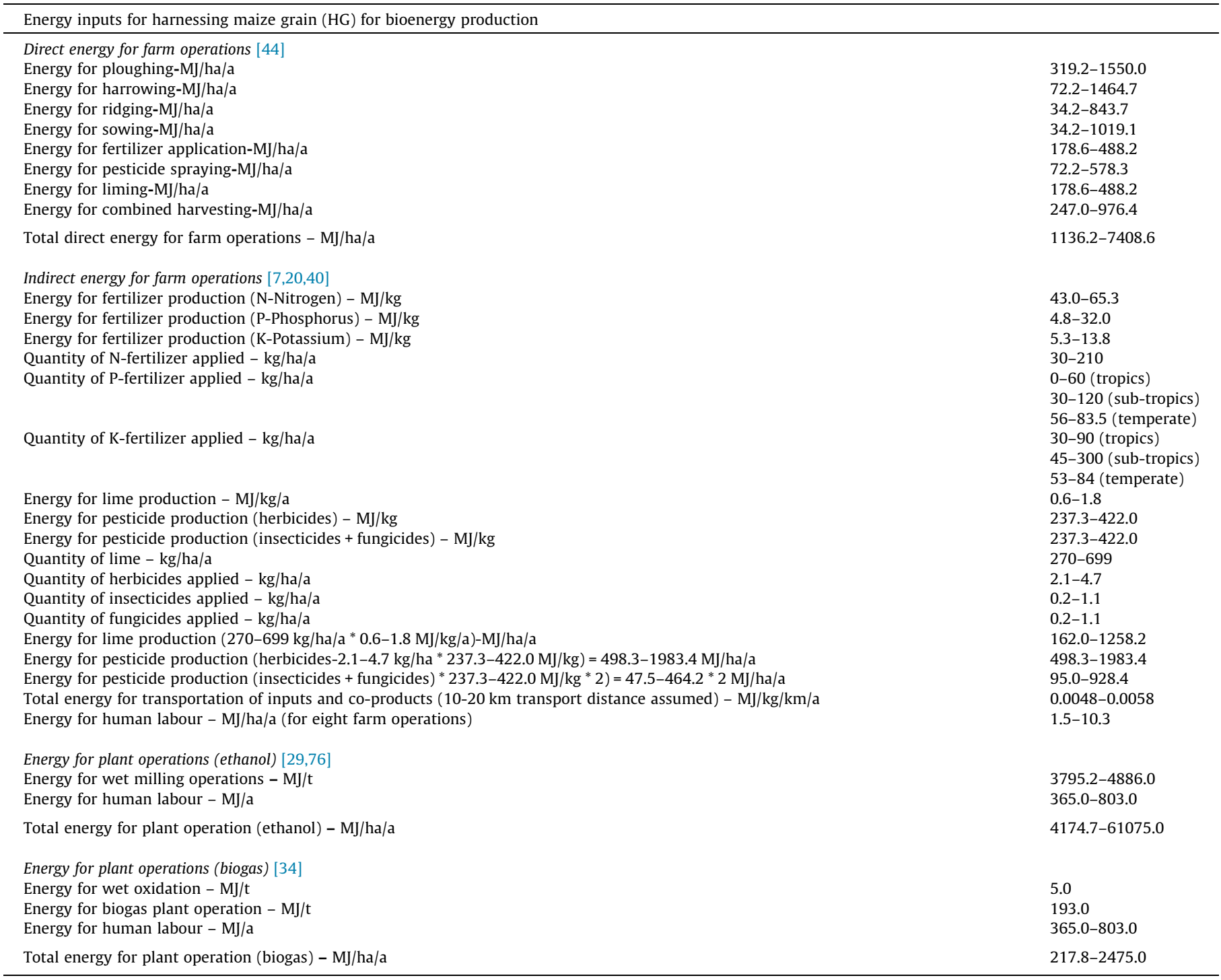

2.2.2. Assumptions made as a result of the substitution of agronomic factor options across the different agronomic factor categories include the following

\section{On alternative tractor power options}

- Three of the tractor options considered (four wheel drive $>50 \mathrm{HP}$, two wheel drive 20-49 HP, single axle riding type 10-19 HP) use the diesel fuel [16,43-46]. Only the <9 HP tractor implementations use gasoline.

- Energy consumption for all farm operations using >50 HP tractors was available in [44]. Energy consumption for other farm operations (aside ploughing) was assumed to be essentially the same as during ploughing operations for the other tractor implementations. This is due to the lack of high resolution data for more detailed assessment. Even though this might be an over-estimation (considering that ploughing is the most energy intensive farm operation), resulting estimates can be regarded as conservative and therefore acceptable. Total energy consumption for all farm operations using the different tractor implementations can be found in Table 3.

\section{On human labour and animal labour options}

- For each hectare under cultivation, humans need 60 days for ploughing (using cutlasses and hoes), 1 day for sowing, 1 day for mulching, 10 days for thinning, 30 days for hand weeding, 4 days for fertilizer and lime application, 3 days for pesticide spraying, and 30 days for harvesting [16,39,47]. - The number of days that animals need for ploughing a hectare of land is assumed to be the same as for completing the other seven operations namely harrowing, ridging, sowing, fertilizer application, liming, pesticide application and harvesting (assuming there are detachable implements for the respective operations) $[16,48,49]$. This is documented in Table 4.

- The daily energy consumption by humans and animals for tedious farm work was assumed to be the maximum daily energy exertable by them. This is documented in Table 3. This was multiplied by the number of days it takes to complete all farm operation (annually per hectare) to obtain total energy input estimates for farm operation using human and animal labour. Maximum daily energy exertable was 
Table 2

Conversion factors for estimating energy outputs of the baseline options.

\begin{tabular}{|c|c|}
\hline \multicolumn{2}{|l|}{ Energy outputs from harnessing harvested grain (HG) for bioenergy production } \\
\hline Energy from maize grain ethanol [77-79] & \\
\hline Volume of ethanol per ton of maize $-1 / t$ & $378.0-435.0$ \\
\hline Calorific energy per litre of ethanol - MJ/l & $21.1-23.4$ \\
\hline Total energy from maize ethanol - (MJ/t) & $7975.8-10179.0$ \\
\hline \multicolumn{2}{|l|}{ Energy from co-products of ethanol production (maize gluten meal) $[7,33,80]$} \\
\hline Proportion of maize gluten meal per ton of maize $-\mathrm{kg} / \mathrm{t}$ & $36.3-57.0$ \\
\hline Energy saved by use of maize gluten meal as herbicide replacement - MJ/kg & $2.1-4.7$ \\
\hline Energy saved by use of maize gluten meal as herbicide replacement - $M J / t$ & $76.2-267.9$ \\
\hline Energy saved by use of maize gluten meal as $\mathrm{N}$-fertilizer replacement - $\mathrm{MJ} / \mathrm{kg}$ & $43.0-65.3$ \\
\hline Percentage of N-fertilizer in maize gluten meal - \% & 10.0 \\
\hline Energy saved by use of maize gluten meal as $N$-fertilizer replacement - $M J / t$ & $325.1-1749.4$ \\
\hline Total energy from co-products (ethanol) - MJ/t & $401.3-2017.3$ \\
\hline \multicolumn{2}{|l|}{ Energy from maize grain biogas [20] } \\
\hline Volatile solids (\%) & $93.0-95.0$ \\
\hline Volume of biogas per ton of maize $-\mathrm{m}^{3} / \mathrm{t}$ & 560.0 \\
\hline Calorific energy per litre of biogas $-\mathrm{MJ} / \mathrm{m}^{3}$ & $21.0-25.0$ \\
\hline Total energy from maize biogas - $(\mathrm{MJ} / \mathrm{t})$ & $10936.8-13300.0$ \\
\hline \multicolumn{2}{|l|}{ Energy from co-products of biogas production (biogas digestate) $[81,82]$} \\
\hline Ratio of digestate to biomass - \% & $96.0-98.0$ \\
\hline Energy for producing lime saved by use of biogas digestate - MJ/kg & $0.6-1.8$ \\
\hline Energy for producing $\mathrm{N}$-fertilizer saved by use of biogas digestate $-\mathrm{MJ} / \mathrm{kg}$ & $43.0-65.3$ \\
\hline Energy for producing P-fertilizer saved by use of biogas digestate - $\mathrm{MJ} / \mathrm{kg}$ & $4.8-32.0$ \\
\hline Energy for producing K-fertilizer saved by use of biogas digestate $-\mathrm{MJ} / \mathrm{kg}$ & $5.3-13.8$ \\
\hline Quantity of Lime in biogas digestate $-\mathrm{kg} / \mathrm{t}$ & 0.8 \\
\hline Quantity of $\mathrm{N}$-fertilizer in biogas digestate $-\mathrm{kg} / \mathrm{t}$ & $3.7-16.1$ \\
\hline Quantity of P-fertilizer in biogas digestate $-\mathrm{kg} / \mathrm{t}$ & $1.8-19.8$ \\
\hline Quantity of K-fertilizer in biogas digestate $-\mathrm{kg} / \mathrm{t}$ & $4.5-32.0$ \\
\hline Energy from co-products (Lime energy replacement) - MJ/t & $0.5-1.4$ \\
\hline Energy from co-products ( $\mathrm{N}$-fertilizer energy replacement - MJ/t & $152.7-1030.3$ \\
\hline Energy from co-products (P-fertilizer energy replacement) - MJ/t & $8.3-620.9$ \\
\hline Energy from co-products (K-fertilizer energy replacement) - MJ/t & $22.9-432.8$ \\
\hline Total energy from co-products (biogas) - MJ/t & 184.4-2085.4 \\
\hline
\end{tabular}

Table 3

Conversion factors for estimating the energy inputs of different tractor power options [43-46].

\begin{tabular}{|c|c|c|}
\hline Tractor power options & Fuel consumption range for ploughing operation (1/ha/a) & $\begin{array}{l}\text { Total energy consumption } \\
\text { equivalent }(\mathrm{MJ} / \mathrm{ha} / \mathrm{a})\end{array}$ \\
\hline$>50 \mathrm{HP}$ tractors & 8.4-32.7 1/ha of diesel (29.9-156.3 1/ha/a of diesel for all farm operations) & $1136.2-7408.6$ \\
\hline 20-49 HP tractors & $22.5-28.0 \mathrm{l} / \mathrm{ha} / \mathbf{a}$ of diesel (180-224.0 1/ha/a of diesel for all farm operations) & $6840.0-10617.6$ \\
\hline 10-19 HP tractors & $5.0-6.3 \mathrm{l} / \mathrm{ha} / \mathbf{a}$ of diesel (40.0-50.4 1/ha/a of diesel for all farm operations) & $1520.0-2389.0$ \\
\hline$<9$ HP tractors & 16.7-25.1 1/ha/a of gasoline (133.6-200.8 1/ha/a of gasoline for all farm operations) & $4582.5-7489.4$ \\
\hline
\end{tabular}

Table 4

Conversion factors for estimating the energy inputs of human and animal labour options $[39,47-49,83]$.

\begin{tabular}{|c|c|c|c|}
\hline Farm labour options & Number of days for ploughing an hectare of land (days) & $\begin{array}{l}\text { Daily energy } \\
\text { consumption } \\
\text { (MJ/day) }\end{array}$ & $\begin{array}{l}\text { Total energy consumption } \\
\text { for farm operations } \\
\text { annually (MJ/a) }\end{array}$ \\
\hline Humans & $\begin{array}{l}60 \text { days for ploughing, } 1 \text { day for sowing, } 1 \text { day for mulching, } 10 \text { days for thinning, } \\
30 \text { days for hand weeding, } 4 \text { days for fertilizer and lime applications, } 3 \text { days for } \\
\text { pesticide spraying, } 30 \text { days for harvesting ( } 139 \text { days for all farm operations) }\end{array}$ & $2.9-4.8 \mathrm{~s}$ & $403.1-681.1$ \\
\hline $\mathrm{Ox}$ & $6-8$ days (48-64 days for all farm operations) & 10.0 & $480.0-640.0$ \\
\hline Buffalo & $6-8$ days (48-64 days for all farm operations) & 9.5 & $456.0-608.0$ \\
\hline Horse & 2 days ( 16 days for all farm operations) & 18.0 & 288.0 \\
\hline Donkey & $10-12$ (80-96 for all farm operations) & 3.0 & $240.0-288.0$ \\
\hline Mule & $6-8$ (48-64 for all farm operations) & 8.5 & $408.0-544.0$ \\
\hline Camel & $2-3$ (16-24 days for all farm operations) & 14.0 & $224.0-336.0$ \\
\hline
\end{tabular}


assumed to be the utilizable fraction of embodied energy (from food and water consumed) for farm operations. This estimation method was preferred to the use of energy for production of human/animal food annually, which may amount to over-estimation considering the fact that humans and animals use energy for food and water ingested for other functions other than farming on non-farming days (e.g. recreation, transport, tourism etc.) [16].

\section{On alternative fertilizer options}

- Energy for production of N, P and K fertilizers was not included in energy inventories for animal manure and biogas digestate use. This is because the nutrients they deliver to the field are free from waste sources. Only the energy for transport and spreading of manure was considered. For biogas digestate, energy for lime $(\mathrm{CaO})$ production and application is also not included in the energy inventory because the nutrient they deliver are from waste sources. Energy for obtaining the biogas digestate is factored into energy for plant operation and transportation of co-products.

\section{On alternative seed sowing options}

- The energy needs for production of hybrid seeds was assumed to be seven times higher than for native seeds $[7,50]$. Due to lack of data, the energy for production of GMO seeds was conservatively assumed to be the average of energy needs for production of native seeds and of hybrid seeds $[16,51,52]$. The $\mathrm{N}$-fertilizer application rates for the adoption of hybrid and GMO seeds was assumed to be higher than those of the native seeds (see Table 5). Estimated potential maize yield as a result of higher fertilization demands of hybrid and GMO seeds is documented in Table S4.

- Energy for production of insecticides and fungicides was not included in the energy inventory for GMO seeds. This is because some GMO varieties do not require such treatment [52,53].

\section{On alternative tillage options}

- The different intensities of fuel consumption for different tillage techniques are documented in Table 6 [44,54].

Table 5

Conversion factors for estimating the energy inputs of alternative seed sowing options $[7,40,52,53]$.

\begin{tabular}{lll}
\hline Seed sowing options & $\begin{array}{l}\mathrm{N}-\text { fertilization application } \\
\text { rates }(\mathrm{kg} / \mathrm{ha} / \mathrm{a})\end{array}$ & $\begin{array}{l}\text { Equivalent energy } \\
\text { consumption }(\mathrm{MJ} / \mathrm{kg} / \mathrm{a})\end{array}$ \\
\hline Native & $30-210$ & $0-14.9$ \\
Hybrid & $120-240$ & 104.3 \\
GMO & $120-240$ & $14.9-104.3$ \\
\hline
\end{tabular}

\section{On alternative irrigation options}

- Operational energy use associated with different irrigation system options is documented in Table 7. No irrigation energy was required for natural (rain-fed) irrigation.

- $\mathrm{N}$-fertilization rates and maize yields increase because of the adoption of artificial irrigation systems (surface, sprinkler and drip irrigation system) require more $\mathrm{N}$ fertilization, and because maize yields respond positively to irrigation [37]. Estimated potential maize yield as a result of increase in fertilization due to adoption of alternative irrigation options is documented in Table S3.

Data from generic agro-climatic zones (tropics, sub-tropics and temperate) was adopted for this study (the coarseness of the scale not withstanding), in order to account for the productivity of maize yield (across the globe) within the context of our energy efficiency assessment.

\subsection{Overall significance of agronomic factors on the energy efficiency of agro-bioenergy production systems}

For reference purposes, it should be noted that obviously, a NEG value less than 0 is unacceptable, since this implies that you are producing less energy than used during the production process $[55,56]$. It may also be useful to rate the NEG of bioenergy sources based on their respective local and/or regional renewable energy targets [35,57]. With regards to EROEI, Hall et al. [19] suggested that the minimum EROEI for an energy source to be capable of supporting socio-economic functions and delivering net benefit to the society is 3 at the farmgate or minemouth. This is based on the assumption that extra two units of energy are required for refinement, blending, transportation and sustenance of other delivery infrastructure before the end user eventually receives one unit of energy provision. EROEI is by definition less than 1 whenever NEG is negative, and equal to or more than 1 when NEG is zero or positive, respectively $[17,58]$.

In order to measure the relative significance of the effects of often overlooked agronomic factors on energy efficiency indicators (i.e. NEG and EROEI) for agro-bioenergy systems, the combined or cumulative effects of the agronomic factors on these two energy efficiency indicators was first estimated by summing together

Table 7

Conversion factors for estimating the energy inputs of alternative irrigation options $[84,85]$.

\begin{tabular}{lll}
\hline Irrigation options & $\begin{array}{l}\text { N-fertilization application } \\
\text { rates }(\mathrm{kg} / \mathrm{ha} / \mathrm{a})\end{array}$ & $\begin{array}{l}\text { Equivalent energy } \\
\text { consumption }(\mathrm{GJ} / \mathrm{ha} / \mathrm{a})\end{array}$ \\
\hline Rain-fed & $30-210$ & 0 \\
Surface & $120-240$ & $0.2-6.5$ \\
Sprinkler & $120-240$ & $3.9-10.4$ \\
Drip & $120-240$ & $3.1-9.5$ \\
\hline
\end{tabular}

Table 6

Conversion factors for estimating the energy inputs of alternative tillage options [44,54].

\begin{tabular}{|c|c|c|}
\hline Tillage options & Fuel consumption range (l/ha/a) & Equivalent energy consumption (MJ/ha/a) \\
\hline Conventional moulboard with pesticide application & $29.9-156.3$ & $1136.2-7408.6$ \\
\hline Conventional moulboard without pesticide application & $25.2-146.0$ & $957.6-6920.4$ \\
\hline Chisel & $23.4-130.6$ & $887.3-6188.1$ \\
\hline Disk & $20.6-105.8$ & $782.8-5014.9$ \\
\hline Ridge plant & $20.6-100.3$ & $783.8-4753.2$ \\
\hline Stubble and mulch & $32.7-97.3$ & $1242.8-4612.0$ \\
\hline Strip-till & $22.1-77.1$ & $841.0-3652.8$ \\
\hline No-till & $23.4-85.2$ & $889.2-4038.5$ \\
\hline
\end{tabular}


(one after the other) the individual positive effects of the highest performing individual agronomic factor options within the five agronomic factor groups examined (namely farm power, tillage, fertilizers, irrigation and seed sowing options).

\section{Results and discussion}

Even though the magnitude of NEG and EROEI indicator values obtained for maize biogas and ethanol production systems, across the three different agro-climatic zones considered (tropics, subtropics and temperate) vary, the effects of individual agronomic factor options follow essentially the same patterns (from no effects to positive and negative effects respectively). This is reported in Table S5. While these observed similarities in pattern make it possible to characterize the results obtained from this study with respect to the different agronomic factor options, generalizations across the generic agro-climatic zones (tropics, sub-tropics and temperate) were however avoided due to the coarseness of the scale of the data. The difference in fertilizer application rates and potential maize yields resulted in corresponding differences in total energy input and output values, as well as variations in final
NEG and EROEI values obtained for each agronomic factor examined across the different agro-climatic zones considered.

\subsection{Individual and combined effects of the different agronomic factors}

Figs. 2-6 depicts the effects of different agronomic factor options on the energy efficiency of maize ethanol and maize biogas production systems, across the different agro-climatic zones. With or without the consideration of associated co-products, maize biogas production systems are by far more energy efficient than maize ethanol production systems across all the agro-climatic zones considered. Accounting for co-products (maize gluten meal as herbicide and $\mathrm{N}$-fertilizer, and biogas digestate as $\mathrm{N}, \mathrm{P}$ and $\mathrm{K}$ fertilizer and lime respectively) in both LCA studies had considerable effects on the NEG and EROEI values of maize biogas (with biogas digestate increasing NEG and EROEI by $1-17 \%$ and $2-6 \%$ respectively) and maize ethanol (with maize gluten meal increasing NEG and EROEI by $84-99 \%$ and $54-68 \%$ respectively). The proportion of NEG and EROEI added by co-products to the energy efficiency of maize ethanol production systems was however much higher than those added to maize biogas production systems. This is because comparatively, the NEG and EROEI of maize biogas production
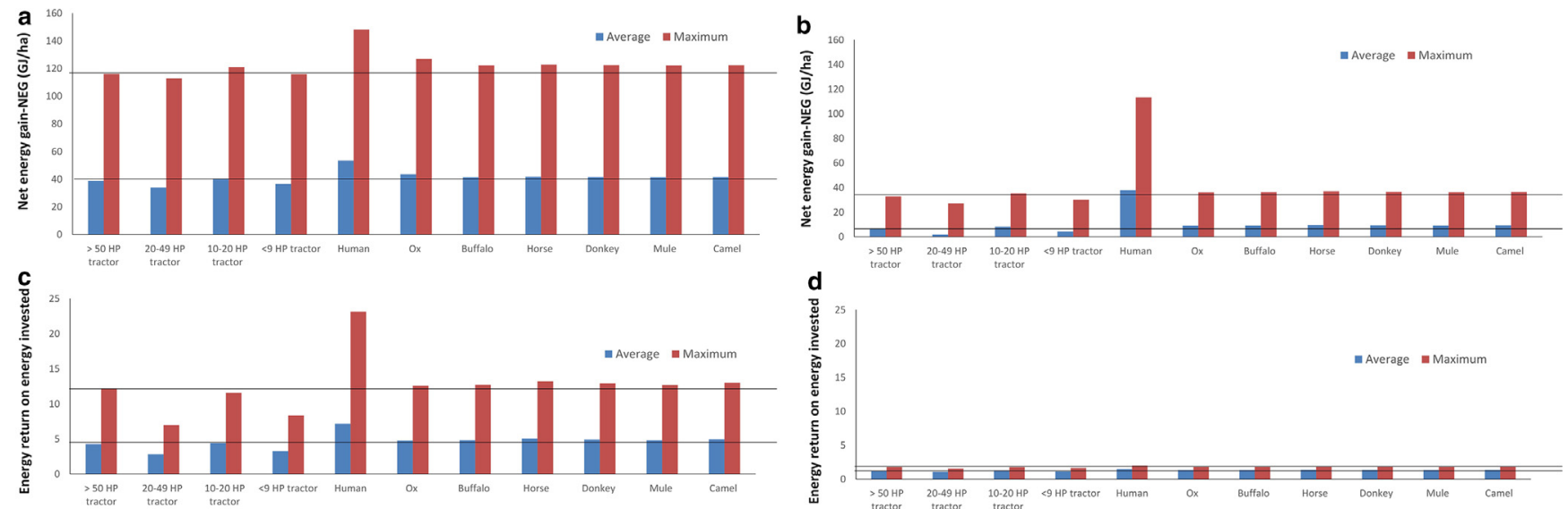

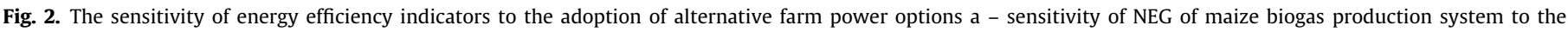

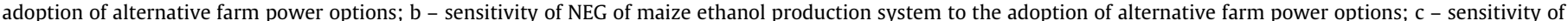

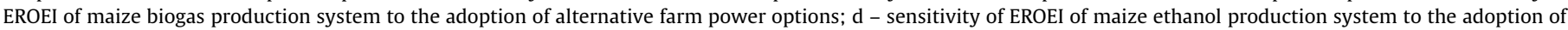
alternative farm power options.
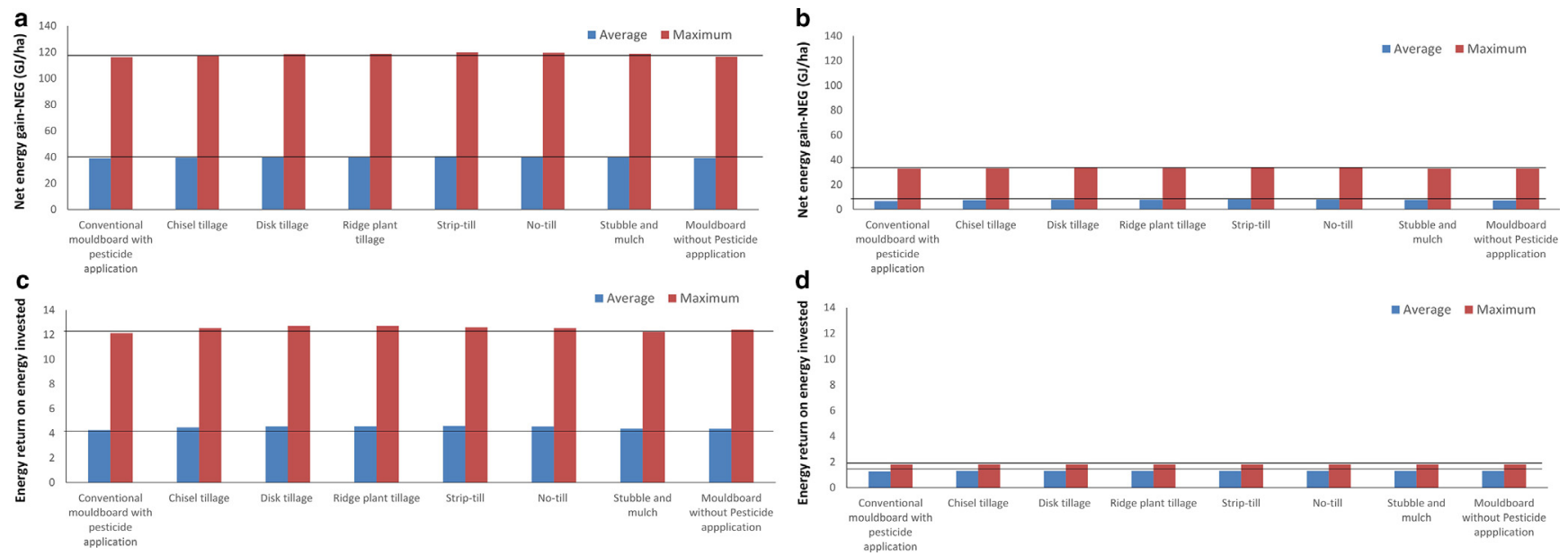

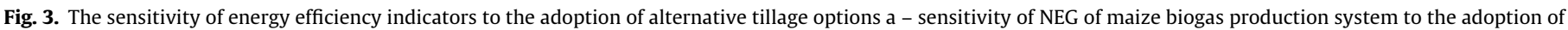

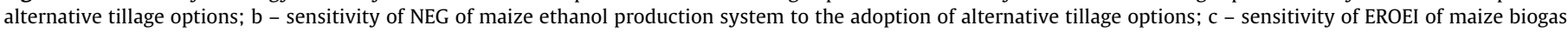

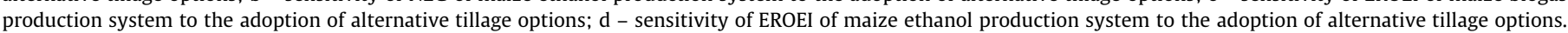



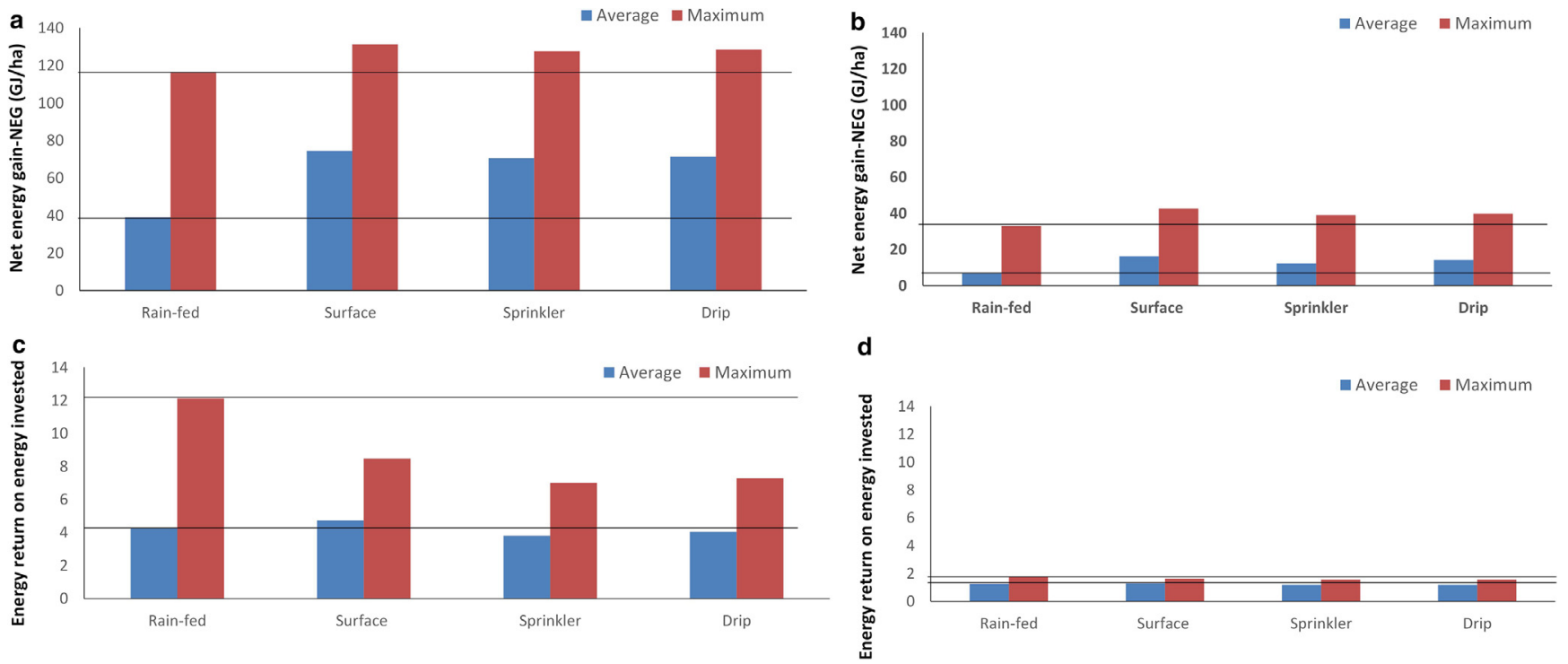

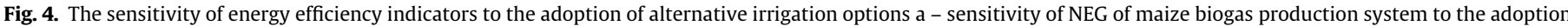

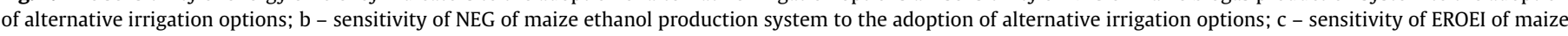

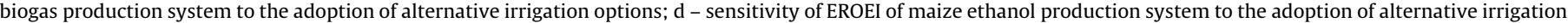
options.
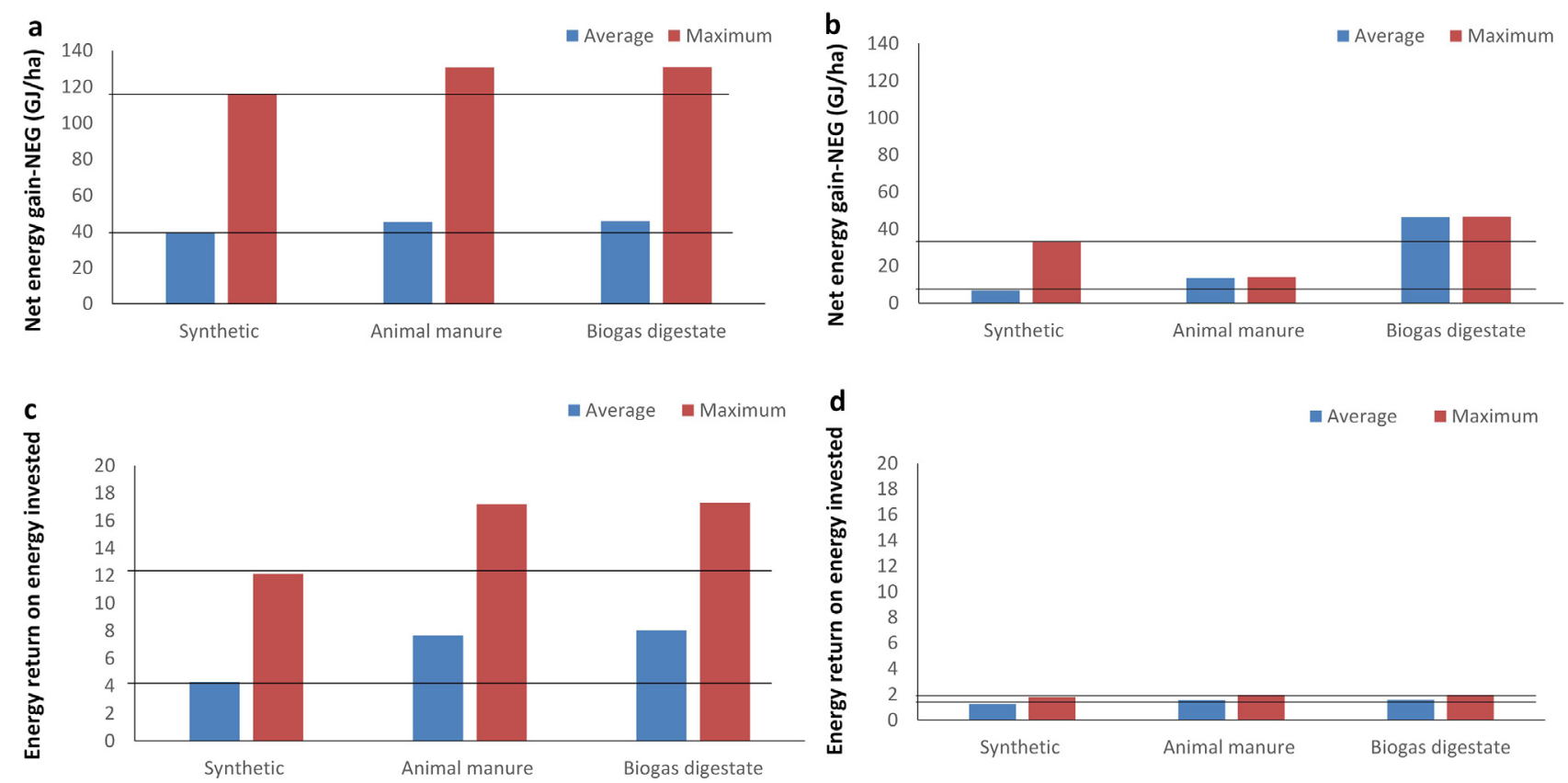

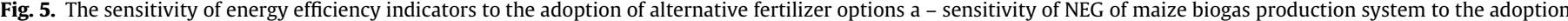

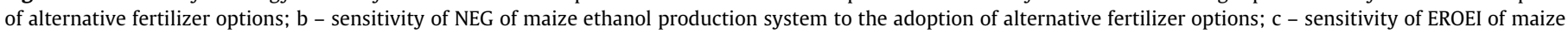

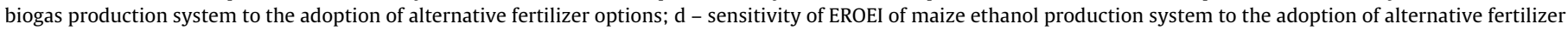
options.

was much higher before the consideration of the co-products. However significant, additional NEG and EROEI added by the coproducts represents only a small proportion of the energy efficiency of the maize biogas production system. For maize ethanol production system, because their NEG and EROEI was much lower before the consideration of co-products, additional NEG and EROEI contributions from co-products took a larger proportion of the energy efficiency of its production system. The energy value of co-products therefore ought to be considered as an integral part of LCA studies designed for assessing agro-bioenergy systems. This will help prevent bias and enhance feasibility within discussions centred around improving resource efficiencies, and promoting a more circular and/or bio-based economy. These effects of coproducts is therefore duly factored-in, within the context of the estimation of the individual, as well as the combined effects of agronomic factor options on the energy efficiency of maize biogas and ethanol production systems.

Bearing in mind the baseline agronomic factor options assumed for the LCA design (i.e. >50 HP tractor, conventional mouldboard tillage, rain-fed irrigation, synthetic fertilizer, and native seeds 
a

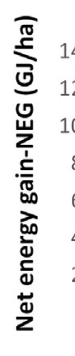

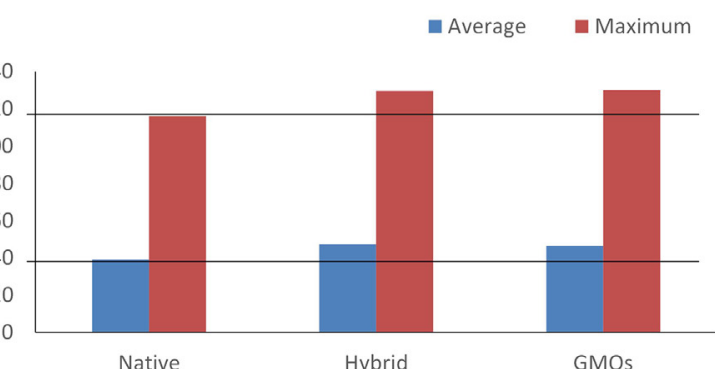

C

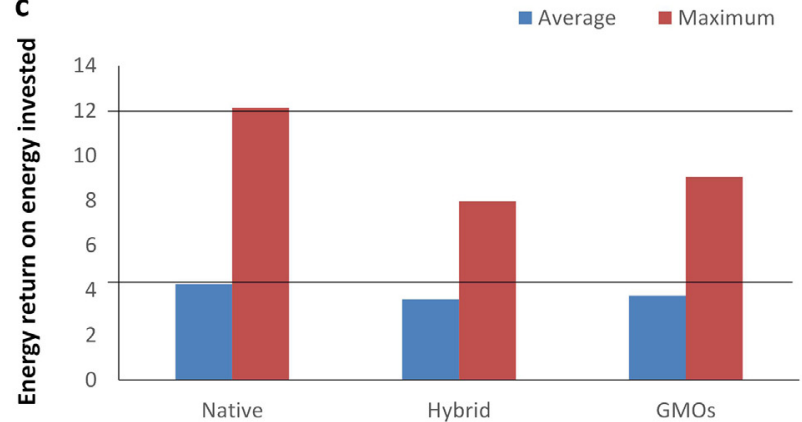

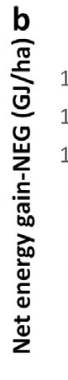

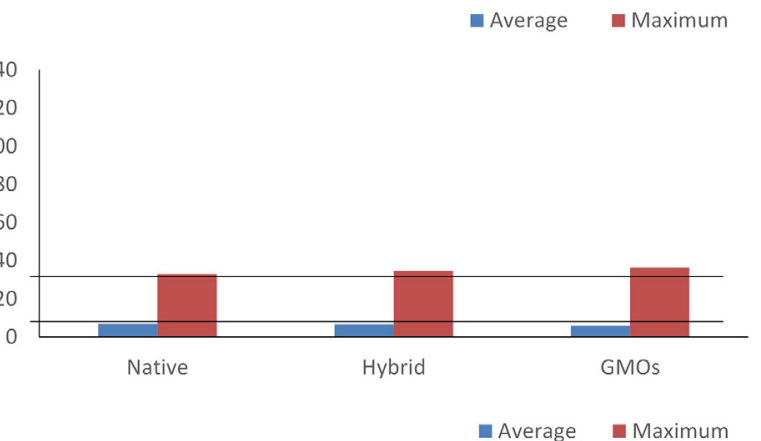

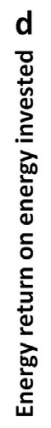

Average Maximum

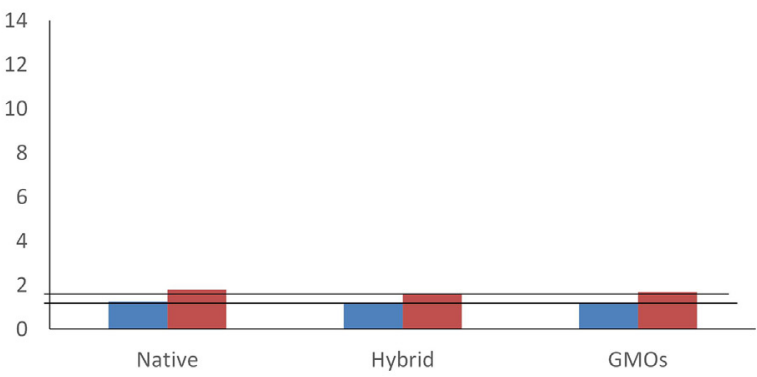

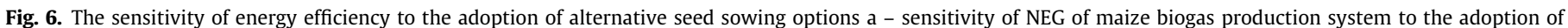

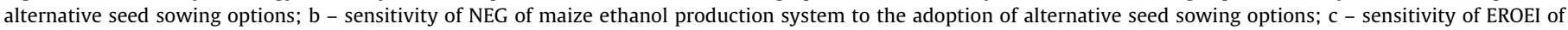

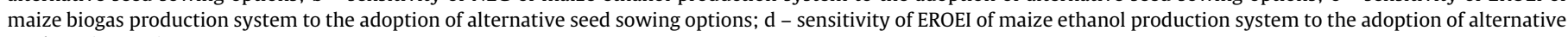
seed sowing options.

for the farm power, tillage, irrigation, fertilizer, and seed sowing categories respectively) individual effects of all other agronomic factor options were assessed by implementing the different assumptions associated with substituting one agronomic factor option with the other (as listed in Section 2.2). In the process of the substitution, general trend of results obtained under this study; especially with regards to the relative sensitivities and individual effects of agronomic factor options on the energy efficiency of maize biogas and maize ethanol production systems were observed. In Figs. 2-6, straight lines were drawn from the lower and upper sensitivity ranges of the baseline options across the bar graphs, in order to ensure visual comparison of the baseline options to the other options in the same agronomic factor category.

In comparison to the $>50 \mathrm{HP}$ tractor, 10-20 Single axle tractor (riding type) might be the most energy efficient tractor option (Fig. 2). From the results obtained (Fig. 2), even though 20-40 HP tractor seem to be the most energy inefficient tractor option, its energy efficiency values may not be significantly different from those of the $>50 \mathrm{HP}$ tractor. This is because the final result shown (Fig. 2) was partly influenced by assumptions that same fuel consumed for ploughing was consumed for all other seven farm operations. While these may be acceptable for avoidance of underestimation of the energy inputs and being over-optimistic in the final analysis of the NEG and EROEI values; in reality, lesser energy is needed for all the other seven farm operations. The results from this study (regarding 20-49 HP tractors) can however be described as conservative, hence, acceptable; especially in the event that the actual energy needed for the all other seven, less energy intensive farm operations remain unknown. There is therefore still need for reliable data from tractor testing exercise that may be devoted towards filling in these data gaps.

The most energy efficient farm power option for agro-bioenergy systems is the use of human labour (Fig. 2). This is followed by the horse, and then the camel in the animal category. This is followed by the donkey, then the buffalo, the mule, and lastly the ox. Both human and animal labour performs better in terms of energy efficiency when compared to tractors driven directly by fossil fuel.
Reduced till (i.e. chisel, disk, ridge plant, stubble and mulch), no-till (i.e. strip-till and no-till) and conventional mouldboard till without pesticide application options are likely to be more energy efficient for agro-bioenergy system than conventional mouldboard tillage (Fig. 3). This can be attributed to their less intensive nature. However as seen in the comparison of NEG and EROEI values for maize biogas production system, and NEG values of maize ethanol production system in Fig. 3, stubble and mulch tillage option may be less energy efficient than conventional mouldboard tillage at the lower sensitivity range, especially if the intensity of the tillage is deeper.

In comparison to rain-fed irrigation systems, artificial irrigation systems (surface, sprinkler and drip) were seen to have higher energy efficiency in terms of NEG at the upper limits (Fig. 4). The adoption of sprinkler and drip irrigation systems for both maize ethanol and biogas production systems might likely lead to a reduction in the EROEI energy efficiency indicator values, at both the lower and upper sensitivity ranges (Fig. 4). The adoption of the surface irrigation system conversely caused a gain in EROEI values, especially at the upper limit of the sensitivity range (Fig. 4).

Both animal manure and biogas digestate were found to be more energy efficient fertilizer options for agro-bioenergy production than synthetic fertilizers (Fig. 5). This was evident at both the upper and lower limits of the sensitivity range of the NEG and EROEI for maize ethanol and maize biogas production systems (Fig. 5). Biogas digestate however has a slight edge over animal manure, because it was assumed to contain some lime $(\mathrm{CaO})$ as compared to animal manure that delivers only N, P and $\mathrm{K}$ fertilizer nutrients.

At the upper and lower sensitivity ranges of NEG for maize biogas production, the use of hybrid and GMO seeds were more energy efficient than those of native seeds (Fig. 6). The adoption of hybrid and GMO seeds however had zero to negative effects on the EROEI of maize biogas production systems (Fig. 6 and Table S5). At both the upper and lower sensitivity ranges of NEG and EROEI for maize ethanol, the deployment of hybrid and GMO seeds was found to be less energy efficient than the use of native 
seeds for agro-bioenergy production (Fig. 6). This is because of the energy cost of the production of hybrid and GMO seeds. Hybrid seeds were found to be the most energy inefficient, even though they guarantee higher maize yields. GMO seeds were found to still be less energy efficient compared to native seeds despite the fact that it was assumed to be capable of saving energy costs for insecticide and fungicide. This implies that the energy it was assumed to save from insecticide and fungicides is still less than the extra energy used in producing them.

The combined effects of the often overlooked agronomic factors further boosted the EROEI of maize biogas from 4.3-12.1 to 15.033.9; and that of maize ethanol from $1.2-1.8$ to 2.1-3.0. The EROEI for maize ethanol is higher than those of previous LCA studies that overlooked these agronomic factors [59,60,2].

The agronomic factors also boosted the net energy gained of both biofuels from $39.0-118.4 \mathrm{GJ} /$ ha to $127.9-257.9 \mathrm{GJ} /$ ha for maize ethanol, and 6.8-32.9 GJ/ha to $99.5-2476.7 \mathrm{GJ} /$ ha for maize biogas. In the same vein, often overlooked agronomic factors accounted for extra 7.5-14.6 times more of NEG from maize ethanol, an extra 2.2-3.3 times more of NEG from maize biogas, an extra 1.7-1.8 times more of EROEI from maize ethanol, and extra 2.8-3.5 times more of EROEI from maize biogas respectively.

\subsection{Overall significance of agronomic factors}

The overall significance of agronomic factors on the energy efficiency of agro-bioenergy production systems was assessed under this study using the energy return on energy invested (EROEI) indicator alone. This is because unlike EROEI, which has a reference minimum value of 3 at farm gate or mine mouth (based on previous bodies of research) $[19,61]$, the reference for NEG is usually assessed based on local or regional renewable energy or total energy targets [19,20,35,57,62].

Since the spatial scale of this study is rather generic, with no specific energy target for any particular locality or region in focus, this study adopted only the EROEI indicator for assessing the overall significance of the results (rather than deploying both NEG and EROEI as done in some of the previous studies).The fact that maize ethanol production system has an initial EROEI below the minimum threshold value of 3 (EROEI of 1.3-1.8) compared to an initial EROEI higher than the minimum threshold value of 3 for maize biogas production systems (EROEI of 4.3-12.1), makes it possible to draw inference on their relative sensitivity when under and above this minimum EROEI threshold value of 3. The EROEI of maize biogas production system was already significant from the onset with values between 4.3 and 12.1. This further stresses the relevance of the use of biogas fueled engines/vehicles for the enhancement of the energetic performance of emerging biofuel based economies e.g. sugarcane based ethanol industry in Brazil etc. $[63,64]$. The EROEI of maize ethanol production system was not significant from the onset (with EROEI values of between 1.2 and 1.8). However, the effects of often overlooked agronomic factor options increased its EROEI to between 2.1 and 3.0 immediately after processing at the wet milling plant. Since this EROEI value for maize ethanol production system was obtained beyond farm gate (immediately after the wet milling plant), it could be considered significant, especially if it is used locally and/or regionally, reducing the energy required for delivering it to the final enduser. This illustrated in Fig. 7.

Considering that the EROEI at farm gate will be the same for both maize ethanol and maize biogas production systems (before entry into the wet digestion or wet milling processes), wet digestion could be said to be far more energy efficient than wet milling process, if the fact that wet milling process has by far many more co-products is not considered. Other co-products of wet milling process that was ignored under this study because they are not directly related to agro-bioenergy production (despite having high energy value) include corn starch, corn oil, fibre, sweetener and steep water. The inclusion of the energy content of the ignored co-products (corn starch, corn oil, fibre, sweetener and steep water) within LCA for determining the energy efficiency of maize ethanol production system, will further improve the overall energy efficiency outlook of maize ethanol production system which deploys the wet milling process.

Also noteworthy is that the NEG and EROEI values obtained under this study may be less than it actually is in reality. This is because this study assumed the maximum transport distance (round trips from farm to input market, conversion plant, end user etc.) was $10-20 \mathrm{~km}$. This however suggests that producing bioenergy locally or regionally on a small scale (e.g. using farm based ethanol and biogas plants etc.) may be more energy efficient (with less environmental impacts) than on large industrial scale. Even though maize biogas is more energy efficient than maize ethanol production systems (with and without the effects of agronomic factor options and co-products), maize ethanol seem to be in higher demand because of the ease of incorporation with dominant

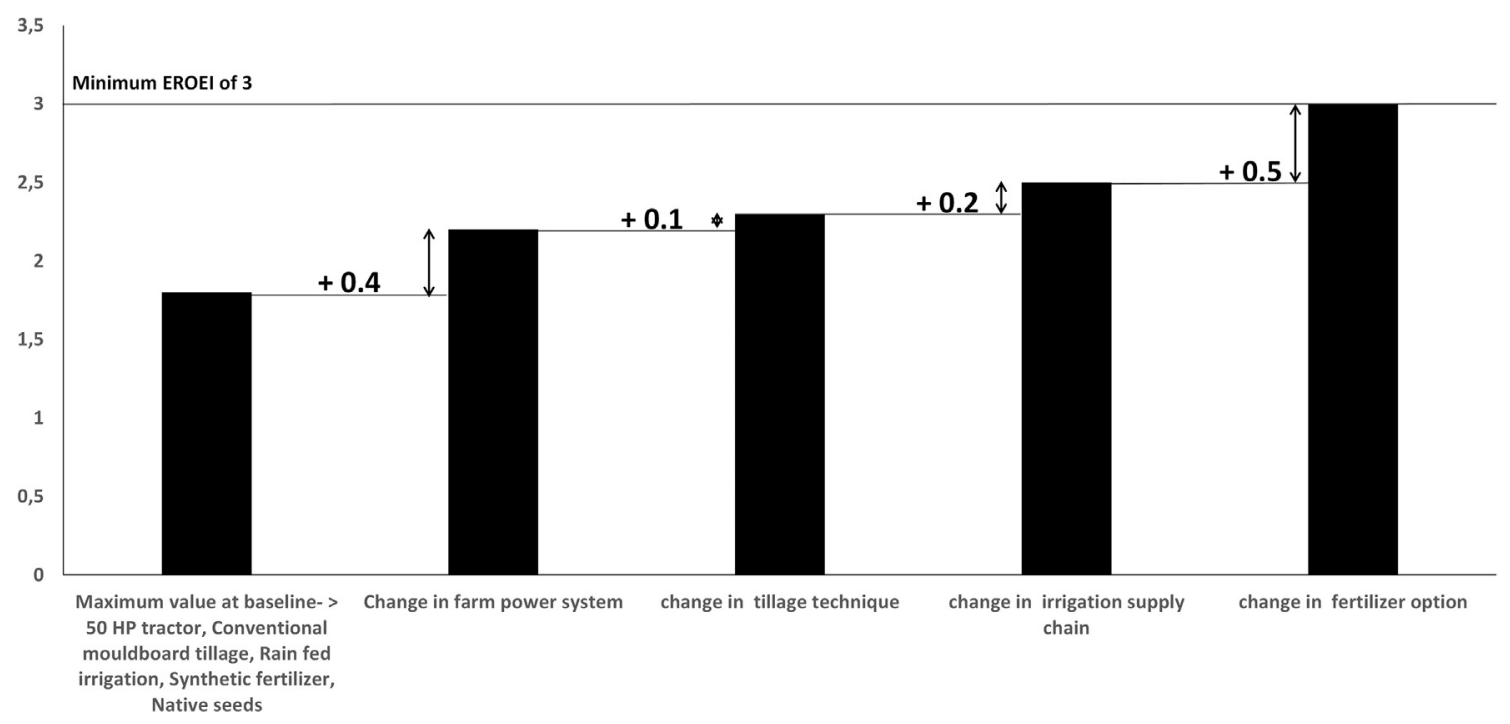

Fig. 7. The significance of the effects of agronomic factor options on the energy efficiency of maize ethanol production systems. 
fossil fuel derivatives (gasoline especially) [2,32]. It is mixed with gasoline for use in new generation engines, and for meeting set biofuel mandates e.g. E10, E15, and E85 gasoline blends in the US; E5 and E85 in Europe; ED95 in Sweden, and E25 and E100 in Brazil $[65,66]$. Higher EROEI values for maize ethanol as a result of the adoption of less energy intensive agronomic factor options implies better efficiency in its role for direct reduction of fossil fuel consumption and associated greenhouse gas emissions [12,67]. Despite higher energy efficiency, biogas (either using maize feedstocks solely or mixed with waste biomass) still has the drawback of inability to mix with natural gas in gas pipes, without the need for energy intensive upgrading processes that will further lower its NEG and EROEI [68], British [31]. While most conventional natural gas pipe have a standard of at least $95 \%$ methane concentration, most biogas have $55-75 \%$ methane concentration (subject to further depreciation from transport leakages) [20,42]. While the mainstream industrial scale use of biogas as natural gas replacement might not be feasible for this reason, biogas use in car vehicle and other engines locally and regionally might be a more feasible option because less energy intensive upgrade compared to those for natural gas replacement will be required $[30,63]$. Even though the required upgrade will also reduce the NEG and EROEI delivered to the society, it is still a feasible option energetically because of the high NEG and EROEI values after the bio-refinery plant stage. The presence of potentially toxic elements (PTEs) in biogas digestate may however also cast doubts on the feasibility of its usage as fertilizer replacements [20,69]. Non-utilization of biogas digestate as a result of the presence of PTEs or need for further upgrading will also further reduce the overall NEG and EROEI deliverable to the society. Despite concerns related to upgrading of biogas, in developing countries where gas and electricity infrastructures are far less developed, private and/or public investments into the establishment of clusters of centralized digesters and/or detached farm scale digesters will help facilitate local and regional biogas production for powering new gas infrastructures and combined heat and power (CHP) plants [70,71]. Even though the use of larger tractors ( $>50$ HP tractors) facilitates intensive mechanization and greater farm work efficiency [72,73]; the use of more energy efficient lower tractor implementation (10-20 HP tractors especially), as well as human and animal labour (as farm power) can still play a role in improving the energy efficiency of biofuel production systems, especially in the developing context $[16,67]$. It can provide new clean energy jobs, prevent loss of farm jobs, and eliminate future constraints associated with the use of natural gas $[15,71]$. It can also provide renewable energy for strengthening the storage and preservation value chains of food systems, for improving the energetic performance of newly evolving biofuel and other renewable energy systems, as well as for facilitating the modest industrialization of rural areas at proximate distances $[74,75]$.

\section{Conclusion}

Agronomic modifications (i.e. change from one agronomic option to the other) can play a significant role in improving the energy efficiency of agro-bioenergy production systems, as well as their applications for different socio-economic functions. Adopting or choosing conservative agronomic factors (e.g. farm power10-20 HP tractors/human labour/animal labour, tillage-reduced till/no-till, fertilizer-animal manure/biogas digestate, irrigationrain-fed/surface, seed sowing options-native seeds etc.) within the context of producing biofuels will help enhance their energy efficiency, hence the need for prioritization for local and regional production and applications. While technological development (in terms of ethanol yield per ton of biomass and the calorific value) may not be significant going forward, agronomic modifica- tion still gives ample room for optimizing the energy efficiency of agricultural based bioenergy production systems from an LCA point of view. Careful consideration of relevant local and regional agronomic factors (e.g. farm power, tillage, fertilizers, irrigation, seed sowing options etc.) should be accorded more attention in subsequent energy efficiency analysis, sustainability assessments and sustainability certification schemes for agro-bioenergy production systems. This will ensure the accuracy of energy efficiency indicator (NEG and EROEI) values obtained locally and regionally and also better inform relevant local and regional stakeholders and policy makers. Furthermore, accurate elicitation of the effects of often overlooked agronomic factors on the energy efficiency of agro-bioenergy production systems rests upon the availability and accuracy of data. Data collection platforms for supply of credible information will still be needed for facilitation of better life cycle inventories, and by extension more accurate energy efficiency assessments. Data regarding other agronomic factors not assessed by study, but whose effects may be important for the energy efficiency of agro-bioenergy production systems also ought to be considered. This will facilitate more accuracy within life cycle assessments conducted for the estimation of energy efficiency indicators of agro-bioenergy production systems. Other agronomic factors yet to be assessed by this study include alternative pesticide options (synthetic VS. organic VS. biological control), different cropping systems (crop rotation VS. mixed cropping VS. monocropping VS. mixed farming VS. shifting cultivation/Bush fallowing) etc.

\section{Acknowledgement}

This study has been supported by the EU through the Marie Curie Innovative Training Networks (ITN) action CASTLE, grant agreement no. 316020. A. Voinov was however also supported by the EU-FP7-308601 COMPLEX project. The authors also wish to thank the reviewers for their proffering suggestions that assisted in improving the manuscript. The contents of this publication reflect only the author's/authors' views and the European Union is not liable for any use that may be made of the information contained therein.

\section{Appendix A. Supplementary material}

Supplementary data associated with this article can be found, in the online version, at http://dx.doi.org/10.1016/j.apenergy.2017. 02.017 .

\section{References}

[1] Fischer G, Schrattenholzer L. Global bioenergy potentials through 2050 . Biomass Bioenergy 2001;20(3):151-9.

[2] Murphy DJ, Hall CAS, Powers B. New perspectives on the energy return on (energy) investment (EROI) of corn ethanol. Environ Dev Sustain 2011;13 (1):179-202.

[3] Shemfe MB, Whittaker C, Gu S, Fidalgo B. Comparative evaluation of GHG emissions from the use of Miscanthus for bio-hydrocarbon production via fast pyrolysis and bio-oil upgrading. Appl Energy 2016;176:22-33.

[4] Demirbas A. Competitive liquid biofuels from biomass. Appl Energy $2011 ; 88: 17-28$

[5] Dale VH, Efroymson RA, Kline KL, Langholtz MH, Leiby PN, Oladosu GA, et al. Indicators for assessing socioeconomic sustainability of bioenergy systems: a short list of practical measures. Ecol Indicat 2013;26:87-102. http://dx.doi. org/10.1016/i.ecolind.2012.10.014.

[6] Münch S, Günther E. A systematic review of bioenergy life cycle assessments. Appl Energy 2013;112:257-73.

[7] Patzek T. Thermodynamics of the corn-ethanol biofuel cycle. Crit Rev Plant Sci 2004;23(6):519-67.

[8] Pimentel D, Marklein A, Toth MA, Karpoff MN, Paul GS, McCormack R, et al. Food versus biofuels: environmental and economic costs. Human Ecol. 2009;37(1):1-12. 
[9] McBride A, Dale VH, Baskaran L, Downing M, Eaton L, Efroymson RA, et al. Indicators to support environmental sustainability of bioenergy systems? Ecol Indicat 2011;11(5):1277-89.

[10] Murphy DJ, Hall CAS, Dale M, Cleveland C. Order from Chaos: a preliminary protocol for determining the EROI of fuels. Sustainability 2011;3:1888-907.

[11] Yamamoto H, Fujino J, Yamaji K. Evaluation of bioenergy potential with a multi regional global-land-use-and-energy model. Biomass Bioenergy 2001;21 (3):185-203.

[12] Hall CAS, Dale BE, Pimentel D. Seeking to understand the reasons for different energy return on investment (EROI) estimates for Biofuels, Sustainability 3(12); 2011. p. 2413-32.

[13] Sánchez B, Iglesias A, McVittie A, Álvaro-Fuentes J, Ingram J, Mills J, et al. Management of agricultural soils for greenhouse gas mitigation: learning from a case study in NE Spain. J Environ Manage 2016;170:37-49.

[14] Pimentel D, Patzek T, Cecil G. Ethanol production: energy, economic, and environmental losses. Rev Environ Contam Toxicol 2007;189:25-41.

[15] Yan J, Lin T. Biofuels in Asia. Appl Energy 2009;86:S1-S10.

[16] Arodudu OT, Helming K, Wiggering H, Voinov A. Bioenergy from low-intensity agricultural systems - an energy efficiency analysis. Energies 2017;10(1):29.

[17] Firrisa MT, van Duren I, Voinov AA. Energy efficiency for rapeseed biodiesel production in different farming systems. Energ Effi 2014;7:79-95.

[18] Hill J, Nelson E, Tilman D, Polasky S, Tiffany D. Environmental, economic, and energetic costs and benefits of biodiesel and ethanol biofuels. Proceed Natl Acad Sci, USA 2006;103(30):1206-11210.

[19] Hall CAS, Balogh S, Murphy DJR. What is the minimum EROI that a sustainable society must have? Energies 2009;2(1):25-47.

[20] Arodudu OT, Voinov A, van Duren I. Assessing bioenergy potentials in rural areas. Biomass Bioenergy 2013;58(38):350-64. http://dx.doi.org/10.1016/i. biombioe.2013.07.020.

[21] EIA. International energy statistics: biofuels production; 2016 [retrieved December 15, 2016].

[22] RFA. Global ethanol production; 2016 <www.afdc.energy.gov/data/10331> [retrieved December 15 2016]

[23] Crafts-Brandner SJ, Salvucci ME. Sensitivity of photosynthesis in a C4 plant, Maize to heat stress. Plant Physiol 2002;129(4):1773-80.

[24] Pimentel D. Ethanol fuels: energy balance, economics, and environmental impacts are negative. Nat Resour Res 2003;12(2):127-34.

[25] Gowik U, Westhoff P. Focus issue on enhancing photosynthesis: the path from C3 to C4 photosynthesis. Plant Physiol 2011;155(1):56-63.

[26] Mrini M, Senhaji F, Pimentel D. Energy analysis of sugarcane production in Morocco. Environ Dev Sustain 2001;3:109-26.

[27] Pimentel D. Impacts of organic farming on the efficiency of energy use in agriculture. Ithaca, NY, United States: The Organic Center State of Science Review, Cornell University; 2006. p. 39.

[28] Shahamat EZ, Asoodar MA, Marzban A, Abdeshahi A. Energy use and economical analysis of sugarcane production in Iran a case study: Debel Khazaeei agro-industry. Int J Agricult Crop Sci 2013;5(3):249-52.

[29] Galitsky C, Worrel E, Ruth M. Energy efficiency improvement and cost saving opportunities for the corn wet milling industry. An energy star guide for energy and plant managers. Berkeley, US: Ernest Orlando Lawrence Berkeley National Laboratory, University of California; 2003. p. 84.

[30] AEBIOM. A biogas road map for Europe; 2009. <http://www.aebiom.org/wp/ wp-content/uploads/file/Publications/Brochure_BiogasRoadmap_WEB.pdf> [retrieved October 6, 2013].

[31] British Biogen. Good practice guidelines: anaerobic digestion of farm and food processing residues. London (England, United Kingdom): British Biogen; 2006. p. 52.

[32] Mulder K, Hagens NJ. Energy return on investment: toward a consistent framework. Ambio 2008;37(2):74-9.

[33] Christians NE. Preemergence weed control using corn gluten meal. U.S. Patent No.5, 030, 268; 1991. p. 63-65.

[34] Uellendahl H, Wang G, Møller HB, Jørgensen U, Skiadas IV, Gavala HN, et al. Energy balance and cost-benefit analysis of biogas production from perennial energy crops pretreated by wet oxidation. Water Sci Technol 2008;58 (9):1841-7.

[35] Arodudu OT, Ibrahim ES, Voinov A, van Duren I. Exploring bioenergy potentials of built-up areas based on NEG-EROEI indicators. Special issue: Integr Ecol Indicat Sustain Urban Ecosyst Evaluat Manage, Ecol Indicat 2014;47(9):67-79. http://dx.doi.org/10.1016/j.ecolind.2014.04.042.

[36] Heisey PW, Mwango W. Fertilizer use and maize production in Sub-Saharan Africa. CIMMYT Economics Working paper 96-01, Mexico, DF, Mexico, CIMMYT. p. 35

[37] IIASA. Table 38 - Maximum attainable crop yield ranges ( $t /$ ha dry weight) for high and intermediate level inputs in tropical, subtropical and temperate environments under irrigated conditions; 2000. <webarchive.iiasa.ac.at/ Research/LUC/GAEZ/tab/t38.htm> [retrieved October 19, 2014].

[38] Msarmo KR, Mhango WG. Yield of maize affected by fertilizer application rates. Bunda College of Agriculture, Crop Science Department; 2004. p. 5.

[39] Belfield S, Brown C. Field crop manual: maize, a guide to upland production in Cambodia. New South Wales Department of Primary Industries; The State of New South Wales, Australia; 2008. p. 43.

[40] IFA. Maize/Corn: Fertilizer Best Management Practices, 2011. p. 33.

[41] FAO. FAOSTAT: Crops, Food and Agriculture Organization of the United Nations; 2016. <www fao.org/faostat/en/\#data/QC> [retrieved September 10 2016].
[42] EUBIA. Anaerobic digestion. European Biomass Industry Association, Brussels, Belgium; 2007. <http://www.eubia.org/index.php/about-biomass/anaerobicdigestion> [retrieved October 12, 2013].

[43] UNAPCAEM. Country Report: Sri Lanka; 2003. <http://unapcaem.org/activities $\% 20 f i l e s / a 07 / c o u n t r y \% 20$ paper-sri\%20lanka(hanoi\%2004).pdf> [retrieved October 6, 2013].

[44] Grisso R, Perumpral JV, Vaughan D, Roberson GT, Pitman R. Predicting tractor diesel fuel consumption. Virginia Cooperative Extension, Virginia Tech, Virginia State University; 2010. p. 442-473.

[45] NCAM. Report of the National Centre for Agricultural Mechanization on Vari Mini Multi-purpose tractor, Ilorin, Nigeria; 2011. p. 10.

[46] Kulkarni M. Greaves launches mini tractor. Business standard: April 15; 2013.

[47] Heney J. Talking about money: explaining the finances of machinery ownership. Rome, Italy: Rural Infrastructure and Agroindustries Division, Food and Agriculture Organization of the United Nations; 2009.

[48] FAO. Chapter 2: Energy for agriculture, environment and natural resources working paper No. 4. Food and Agriculture Organization of the United Nations, Rome, Italy; 2000.

[49] Joshi DD. Livestock rearing. In: Myers ML, Stellman JM, editors. International Labor Organization, Geneva. Switzerland; 2011.

[50] Heichel G. Private communication. US: University of Illinois; 2004.

[51] GMO Compass. Maize (corn); 2010. <http://www.gmo-compass.org/ eng/database/plants/52.maize.html> [retrieved October 6, 2013].

[52] Goldenberg S. GM corn being developed for fuel instead of food. London, UK: The Guardian; 2011.

[53] Goho AM. Corn primed for making biofuel. MIT Technology review Massachusetts, US; 2008. <http://www.technologyreview.com/news 409913/corn-primed-for-making-biofuel/> [retrieved October 12, 2013].

[54] Cropwatch. Tillage systems descriptions. Cropwatch, University of NebraskaLincoln, US; 2013. <http://cropwatch.unl.edu/tillage> [Retrieved October 12 2013].

[55] Cleveland CJ. Net energy from the extraction of oil and gas in the United States. Energy 2005;30:769-82. 563.

[56] Meyer AKP, Ehimen EA, Holm-Nielsen JB. Bioenergy production from roadside grass: a case study of the feasibility of using roadside grass for biogas production in Denmark. Resour Conserv Recycl 2014;93:124-33. http://dx.doi org/10.1016/i.resconrec.2014.10.003.

[57] Voinov A, Arodudu OT, van Duren I, Morales J, Qin L. Estimating the potentia of roadside vegetation for bioenergy production. J Clean Prod 2015;102 (19):213-25. http://dx.doi.org/10.1016/i.jclepro.2015.04.034.

[58] Gagnon N, Hall CAS, Brinker L. A preliminary investigation of the energy return on energy invested for global oil and gas extraction. Energies 2009;2:490-503.

[59] Kim S, Dale BE. Life cycle assessment of various cropping systems utilized for producing biofuels: bioethanol and biodiesel. Biomass Bioenergy 2005;29:426-39.

[60] Pimentel D, Patzek T. Ethanol production using corn, switchgrass and wood; biodiesel production using soybean. In: Pimentel D, editor. In Biofuels, solar and wind as renewable energy systems: benefits and risks. Dordrecht, the Netherlands: Springer Science+Business Media B.V.; 2008. p. 357-94.

[61] Murphy DJ, Hall CAS. Year in review-EROI or energy return on (energy) invested. Ann N Y Acad Sci 2010;1185:102-18.

[62] van Duren I, Voinov A, Arodudu OT, Firrisa MT. Where to produce rapeseed biodiesel and why? Mapping European RME energy efficiency in differen agro-ecological conditions. Renewable Energy 2015;74(6):49-59. http://dx doi.org/10.1016/i.renene.2014.07.016.

[63] Moraes BS, Junqueira TL, Pavanello LG, Cavaletta O, Mantelatto PE, Bonomi A et al. Anaerobic digestion of vinasse from sugarcane biorefineries in Brazil from energy, environmental, and economic perspectives: Profit or expense? Appl Energy 2014;113:825-35.

[64] Moraes BS, Zaiat M, Bonomi A. Anaerobic digestion of vinasse from sugarcane ethanol production in Brazil: challenges and perspectives. Renew Sustain Energy Rev 2015;44:888-903.

[65] RFA. Accelerating industry innovation - 2012 ethanol industry outlook Renewable Fuels Association; 2012. p. 33 <http://ethanolrfa.3cdn.net/ d4ad995ffb7ae8fbfe_1vm62ypzd.pdf> [retrieved December 14 2016].

[66] GRFA. Global biofuel mandates, global renewable fuels alliance; 2016 <http://globalrfa.org/biofuels-map/> [retrieved December 14, 2016].

[67] Savage N. Fuels options: the ideal biofuel. Nature 2011;474:S9-S11.

[68] Monnet F. An introduction to anaerobic digestion of organic wastes. Fina Report, Remade Scotland; 2003. p. 48

[69] Swedish Gas Association. Biogas in Sweden, Energigas Sverige; 2011. p. 27

[70] Zhou A, Thomson E. The development of biofuels in Asia. Appl Energy 2009;86: S11-20.

[71] Srirangan L, Akawi L, Moo-Young M, Chou CP. Towards sustainable production of clean energy carriers from biomass resources. Appl Energy 2012;100:172-86.

[72] Romanelli TL, Milan M. Material flow determination through agricultural machinery management. Scientia Agricola 2010;67(4):375-83.

[73] Mantoam EJ, Romanelli TL, Gimenez LM. Energy demand and greenhouse gases emissions in the life cycle of tractors. Biosyst Eng 2016;151:158-70.

[74] Lynd LR, Woods J. Perspectives: a new hope for Africa. Nature 2011:474:S20-1.

[75] Moraes BS, Triolo JM, Lecona VP, Zaiat M, Sommer SG. Biogas production within the bioethanol production chain: use of co-substrates for anaerobic digestion of sugar beet vinasse. Bioresour Technol 2015;190:227-34. http: dx.doi.org/10.1016/i.biortech.2015.04.089. 
[76] Graboski MS. Fossil energy use in the manufacture of corn ethanol. A report for the National Corn Growers Association, Colorado School of Mines; 2002, p. 113.

[77] White PJ, Johnson LA. Corn Chemistry and Technology, American Association of Cereal Chemists; 2003.

[78] Bonnardeaux J, 2007. Potential Uses for Distillers Grains, Department of Agriculture and Food, Government of Western Australia; Western Australia, Australia, 11. http://archive.agric.wa.gov.au/objtwr/imported assets/content/sust/biofuel/potentialusesgrains042007.pdf

[79] Naylor, R.L., Liska, A.J., Burke, M.B., Falcon, W.P., Gaskell, J.C., Rozelle, S.D., Cassman, K.G., 2007. The Ripple Effect: Biofuels, Food Security, and the Environment, Environment Magazine, Philadelphia, United States, W.P., 49 (9), 30-43.

[80] ORNL. Bioenergy conversion factors. Oak Ridge National Laboratory, U.S Department of Energy; 2005. <http://bioenergy.ornl.gov/papers/misc/ energy_conv.html> [retrieved October 12, 2013].
[81] Gebrezgabher SA, Meuwissen MPM, Oude Lansink AGJM, Prins BAM. Economic analysis of anaerobic digestion: a case of green power biogas plant in the Netherlands. In: Proceedings of the 18th international farm management congress, July 2009, Illinois, USA: Bloomington/Normal; 2009. p. 231-44.

[82] KWS. Biogas in practice. A report by KWS UK Limited, Hertfordshire, UK; 2012. p. 38.

[83] Naudé-Moseley B, Jones PA. Donkeys don't need roads. Farmer's Weekly, 92046/Grow 131: 4; 22 November, 2002.

[84] Jacobs S. Comparison of life cycle energy consumption of alternative irrigation systems (dissertation). Faculty of Engineering and Surveying - Department of Agricultural, Civil and Environmental Engineering, University of Southern Queensland, Australia; 2006. p. 53.

[85] Jackson T. An appraisal of the on-farm water and energy nexus in irrigated agriculture (Thesis). New South Wales, Australia: School of Environmental Sciences, Faculty of Science, Charles Sturt University; 2009. 